\title{
PENGARUH MODEL PEMBELAJARAN EXPERIENTIAL LEARNING DENGAN MEDIA AUDIOVISUAL TERHADAP KEMAMPUAN MENULIS TEKS PROSEDUR KOMPLEKS PADA SISWA KELAS X SMA NEGERI 5 MEDAN TAHUN PEMBELAJARAN 2016/2017
}

\author{
Oleh \\ Basuki Rachmat Sinaga \\ Prof. Dr. Khairil Ansari, M.Pd.
}

Penelitian ini bertujuan untuk mengetahui pengaruh model pembelajaran experiential learning dengan media audiovisual terhadap kemampuan menulis teks prosedur kompleks pada siswa kelas x SMA Negeri 5 Medan Tahun Pembelajaran 2016/2017 yang terdiri dari 9 kelas dengan jumlah siswa 360 orang. Sampel yang diambil adalah 40 orang. Instrumen yang digunakan untuk menjaring data adalah tes uraian. Penelitian ini bersifat eksperimen dengan model one group pre-test post-test design. Distribusi data yang diperoleh menunjukkan bahwa kemampuan menulis teks prosedur kompleks sebelum menggunakan model pembelajaran experiential learning dengan media audiovisual berada dalam kategori kurang dengan nilai rata-rata sebesar 57,62. Kemampuan menulis teks prosedur kompleks sesudah menggunakan model embelajaran experiential learning dengan media audiovisual berada dalam kategori baik dengan nilai rata-rata sebesar 80,27. Berdasarkan perhitungan uji normalitas menunjukkan bahwa data pre-test dan data post-test berdistribusi normal. Hajil uji homogenitas membutikan bahwa sampel berasal dari populasi yang homogen. Pengujian hipotesis dilakukan dengan menggunakan uji "t". Hasil perhitungan uji "t" pada taraf signiikan $5 \%$ diperoleh $t_{\text {hitung }}$ lebih besar dari $t_{\text {tabel }}$ yaitu $10,58>2,02$, maka hipotesis nihil $\left(\mathrm{H}_{\mathrm{o}}\right)$ ditolak dan hipotesis alternatif $\left(\mathrm{H}_{\mathrm{a}}\right)$ diterima. Hal ini membuktikan bahwa model pembelajaran experiential learning dengan media audiovisual berpengaruh signifikan terhadap kemampuan menulis teks prosedur kompleks siswa kelas X SMA Negeri 5 Medan Tahun Pembelajaran 2016/ 2017.

Kata Kunci : Experiential Learning, Media Audiovisual, Teks Prosedur Kompleks.

\section{PENDAHULUAN}

Bahasa Indonesia merupakan satu bentuk alat komunikasi dan sebagai alat pemersatu bangsa. Bahasa Indonesia juga merupakan salah satu hasil kebudayaan yang harus dipelajari dan diajarkan. Pengajaran bahasa Indonesia pada hakikatnya merupakan salah satu sarana mengupayakan pembinaan dan pengembangan bahasa Indonesia secara terarah. Maka dari itu proses pengajaran bahasa Indonesia diharapkan siswa mempunyai kemampuan yang memadai untuk menggunakan bahasa Indonesia secara baik dan benar.

Secara umum keterampilan berbahasa meliputi empat aspek, yaitu kemampuan menyimak, berbicara, membaca, dan menulis. Keempat aspek tersebut saling berkaitan satu sama lain. Pada dasarnya belajar bahasa diawali dengan menyimak, berangsur-angsur meniru, 
dan mengucapkannya kembali. Kemudian memahami bahasa tersebut dalam bentuk tulisan, yaitu dengan belajar membaca. Pada tahap akhir kemampuan mengembangkan bahasa tulisan yang disebut dengan menulis (Tarigan, 1986:1).

Sehubungan dengan itu, Nurgiyantoro (2012: 423) menyatakan "Menulis merupakan salah satu keterampilan berbahasa untuk menuangkan ide dalam bentuk tulisan." Menulis sebagai wujud kemahiran berbahasa mempunyai manfaat yang besar bagi kehidupan manusia, khususnya para siswa. Pada saat menulis, siswa dituntut berpikir untuk menuangkan gagasan secara tertulis berdasarkan pengetahuan dan pengalaman yang dimiliki. Aktivitas tersebut memerlukan kesungguhan untuk mengolah, menata, dan mempertimbangkan secara kritis gagasan yang akan dituangkan dalam bentuk tulisan.

Untuk meningkatkan minat belajar siswa, khususnya dalam hal menulis tidaklah mudah. Itu sangat bergantung pada kesiapan siswa untuk terlibat secara personal dalam proses pembelajaran, sehingga seorang guru harus mampu menciptakan situasi yang kondusif serta memberikan kegiatan yang menarik sebagai proses untuk memulai pelajaran (Indriana, 2012:94).

Salah satu pembelajaran bahasa Indonesia berbasis teks dalam Kurikulum 2013 yaitu pembelajaran teks prosedur kompleks yang merupakan Kompetensi Dasar (KD) yang harus dikuasai oleh setiap siswa di kelas X SMA/SMK. Dengan Kompetensi Dasar (KD) 4.2 Memproduksi teks prosedur kompleks yang koheren sesuai dengan karakteristik teks yang akan dibuat baik secara lisan maupun tulisan. Memproduksi adalah menghasilkan; mengeluarkan hasil (Depdiknas, 2008:1103). Dalam hal ini siswa dituntun untuk memproduksi sebuah tulisan. Tulisan yang akan dibuat siswa adalah teks prosedur kompleks.

Teks prosedur kompleks adalah teks yang berisi langkah-langkah atau tahapan yang harus ditempuh untuk mencapai tujuan (Kemdikbud, 2014:36). Dalam pembelajaran menulis teks prosedur kompleks, siswa dituntut untuk mengetahui struktur teks, isi teks, ciri-ciri teks, syarat teks, dan cara menulis teks prosedur kompleks. Setelah siswa mengetahui hal-hal tersebut, siswa dituntut untuk lebih kreatif dalam menuangkan gagasan-gagasan dan idenya dalam menulis teks prosedur kompleks. Dengan demikian, teks prosedur kompleks yang ditulis oleh siswa diharapkan sudah menjadi sebuah teks prosedur kompleks yang baik dengan memenuhi struktur dan kaidah teks prosedur kompleks.

Namun, mengingat teks prosedur kompleks adalah teks yang baru muncul dalam pelajaran bahasa indonesia kelas X Kurikulum 2013, masih banyak siswa yang bingung akan pengertian dan struktur teks prosedur kompleks. Pengetahuan siswa tentang unsur-unsur dan langkah-langkah dalam menulis teks prosedur kompleks pun masih tertukar dengan unsur- 
unsur dan langkah-langkah dalam teks prosedur biasa. Jika pengetahuan siswa masih rendah mengenai teks prosedur kompleks, maka kemungkinan untuk menghasilkan teks prosedur kompleks yang baik akan sulit dicapai.

Pembelajaran menulis telah lama menjadi satu masalah dalam sistem pembelajaran bahasa Indonesia. Trimantara (2005:2) menyatakan, "Beberapa faktor yang menyebabkan tidak tercapainya pembelajaran menulis adalah 1) rendahnya tingkat penguasaan kosa kata sebagai akibat rendahnya minat baca, 2) kurangnya penguasaan keterampilan mikrobahasa, seperti penggunaan tanda bahasa, kaidah-kaidah penulisan, penggunaan kelompok kata, penyusunan klausa dan kalimat dengan struktur yang benar, sampai penyusunan paragraf, 3) kesulitan menemukan metode pembelajaran menulis sesuai dengan kondisi dan kemampuan siswa, serta 4) ketiadaan atau keterbatasan media pembelajaran menulis yang efektif." Sehubungan dengan itu, Graves (dalam Yunus, 2009:14) juga menyatakan, "Seseorang enggan menulis karena tidak tahu untuk apa dia menulis, merasa tidak berbakat menulis, dan merasa tidak tahu bagaimana harus menulis."

Berdasarkan penelitian sebelumnya oleh Aulia Ratna Sari dalam pembelajaran menulis teks prosedur kompleks pada siswa kelas X SMA Negeri 6 Yogyakarta pada Tahun Pembelajaran 2014/2015." Dalam penelitian tersebut nilai rata-rata siwa pada kondisi awal sebesar 58,6 dengan KKM (Kriteria Ketuntasan Minimal) sebesar 70. Pada siklus I nilai ratarata siswa sebesar 66,7, dan pada siklus II sebesar 73,7. Masalah penelitian diambil dari pengalaman empiris bahwa kemampuan siswa dalam menulis masih rendah.

Sehubungan dengan itu, setelah dilakukan wawancara oleh penulis dengan salah satu guru mata pelajaran bahasa indonesia SMA Negeri 5 Medan, Ibu B.A Harianja, S.S., penulis dapat mengetahui gambaran dalam pembelajaran teks prosedur kompleks minat belajar siswa yang rendah, kebanyakan siswa malas dalam menulis teks. Dalam menulis teks prosedur kompleks, siswa hanya mampu menuliskan rangakain teks yang belum lengkap berdasarkan strktur dan ciri kebahasaannya. Salah satu masalah klasik yang tak pernah hilang adalah kegiatan menulis masih dirasa sebagai hal yang sulit untuk siswa. Selain itu, kondisi siswa yang menurut guru sulit untuk diatur dan lambat menerima pembelajaran, memaksa guru banyak melakukan teknik ceramah. Berdasarkan alasan-alasan tersebut menyebabkan rendahnya nilai siswa dalam menulis teks prosedur kompleks. Adapun nilai rata-rata yang diperoleh siswa dalam menulis teks prosedur kompleks adalah 72,5 dari nilai KKM 75.

Berdasarkan hasil observasi yang penulis lakukan pada siswa kelas X MIA 5, SMA Negeri 5 Medan dapat diketahui bahwa kemampuan siswa dalam menulis teks prosedur kompleks belum mumpuni atau dapat dikatakan rendah. Siswa cenderung sulit menuangkan 
ide dan gagasannya ke dalam tulisan, terlebih jika siswa diminta untuk menuliskan sebuah tulisan yang sifatnya memberikan informasi kepada pembaca. Sebagian besar siswa melakukan kesalahan akibat keterbatasan referensi. Selain itu, dalam pembelajaran di kelas, penggunaan metode, teknik, media, dan strategi yang digunakan oleh guru kurang menarik dan monoton, sehingga membuat siswa menjadi bosan. Guru juga kurang memberikan motivasi belajar dan penekanan bahwa bisa menulis teks prosedur kompleks itu penting dan bisa berguna bagi diri siswa sendiri dan orang lain.

Pentingnya keterampilan menulis bagi siswa, membuat guru yang memegang peranan penting. Perlu adanya perbaikan dan upaya peningkatan dalam pembelajaran yang bertujuan untuk mengaktifkan siswa dalam kegiatan belajar agar memperoleh hasil belajar yang baik. Salah satu cara yang dapat dilakukan untuk memperbaiki kondisi pembelajaran tersebut adalah dengan melakukan inovasi. Inovasi tersebut beruoa pengunaan dan pengembangan model pembelajaran. Adapun model pembelajaran yang akan digunakan penulis yaitu model pembelajaran experiential learning dengan dibantu penggunaan media video agar menarik minat siswa untuk belajar.

Pembelajaran dengan model experiental learning diperkenalkan oleh David Kolb yang mendefinisikan belajar sebagai proses bagaimana pengetahuan diciptakan melalui perubahan bentuk pengalaman. Model ini disebut juga dengan model pembelajaran berbasis pengalaman yang mendefinisikan belajar sebagai proses mengkonstruksikan pengetahuan melalui transformasi pengalaman. Belajar dari pengalaman mencakup keterkaitan antara berbuat dan berpikir. Menurut Atherton (dalam Fathurrohman, 2015:128) "Pada konteks belajar pembelajaran berbasis pengalaman dapat dideskripsikan sebagai proses pembelajaran yang merefleksikan pengalaman secara mendalam dan dari sini muncul pemahaman baru atau proses belajar. Pembelajaran berbasis pengalaman memanfaatkan pengalaman baru dan reaksi pembelajar terhadap pengalamannya untuk membangun pemahaman dan transfer pengetahuan, keterampilan, dan sikap."

Sehubungan dengan itu Fathurrohman (2015:129) menyatakan, "Experiential Learning adalah proses belajar, proses perubahan yang menggunakan pengalaman sebagai media belajar atau pembelajaran bukan hanya materi yang bersumber dari buku atau pendidik." Di dalam proses belajar dengan model ini guru berfungsi sebagai seoarang fasilitator. Artinya, guru hanya memberikan arah (guide) tidak memberikan informasi secara sepihak dan menjadi sumber pengetahuan tunggal. Setelah siswa melakukan suatu aktivitas belajar, selanjutnya siswa akan mengabstraksi sendiri pengalamannya. Misalnya apa yang dirasakan oleh siswa pada saat menyelenggarakan pertunjukan, permasalahan yang dihadapi, 
bagaimana cara menyelesaikan masalah, dan apa yang dapat dipelajari untuk memperbaiki diri di masa depan. Jadi, guru lebih menggali pengalaman siswa itu sendiri.

Menurut Sanjaya (2014:162), "Proses pembelajaran merupakan proses komunikasi. Dalam suatu proses komunikasi selalu melibatkan tiga komponen pokok, yaitu komponen pengirim pesan (guru), komponen penerima pesan (siswa), dan komponen pesan itu sendiri yang biasanya berupa materi pelajaran.” Kadang-kadang dalam proses pembelajaran terjadi kegagalan komunikasi. Artinya, materi pelajaran atau pesan yang disampaikan guru tidak dapat diterima oleh siswa dengan optimal, artinya tidak seluruh materi pelajaran dapat dipahami dengan baik oleh siswa; lebih parah lagi siswa sebagai penerima pesan salah menangkap isi pesan yang disampaikan. Untuk menghindari semua itu, maka guru dapat menyusun strategi pembelajaran dengan memanfaatkan media dan sumber belajar. Jadi dalam penelitian ini, peneliti juga memanfaatkan media pembelajaran audiovisual dalam proses pembelajaran. Penggunaan media bertujuan agar siswa dapat berpikir kritis, kreatif, memiliki kepekaan, serta mempertajam daya pikir, dan imajinasinya.

Berdasarkan uraian di atas, maka permasalahan yang diangkat oleh penulis adalah "Pengaruh Model Pembelajaran Experiential Learning dengan Media Audiovisual Terhadap Kemampuan Menulis Teks Prosedur Kompleks pada Siswa Kelas X SMA Negeri 5 Medan Tahun Pembelajaran 2016/2017."

\section{METODE PENELITIAN}

Metode penelitian merupakan cara yang digunakan peneliti untuk menjawab permasalahan dalam penelitian. Oleh karena itu, metode penelitian sangat mententukan berhasil tidaknya suatu penelitian yang dilaksanakan. Sebagaimana yang diungkapkan Arikunto (2009:100), "metode penetian adalah cara yang digunakan peneliti untuk mengumpulkan data."

Penelitian ini merupakan penelitian kuantitatif. Adapu metode yang dihunakan adalah metode eksperimen dengan model one group pre-test post-test design, yaitu eksperimen yang dilaksanakan pada satu kelompok saja tanpa kelompok pembanding. Eksperimen tersebut dilakukan bertujuan untuk melihat akibat dari suatu perlakuan pada objek selidik. Hal ini sesuai dengan pendapat Arikunto (2009:207), "Penelitian eksperimen adalah penelitian yang dimaksud untuk mengetahui ada tidaknya akibar dari 'sesuatu' yang dikenakan pada objek selidik." Teknik pengambilan data dilakukan dua kai yaitu sebelum eksperimen (pre-test) dan sesudah eksperimen (post-test). Penelitian ini bertujuan untuk mengetahui adanya pengaurh penggunaan model pembelajaran experiential learning dengan media audiovisual 
terhadap kemampuan menulis teks prosedur kompleks pada siswa kelas X SMA Negeri 5 Medan tahun pembelajaran 2016/2017.

Data yang diperoleh selanjutnya dianalisis secara statistik dengan langkah-langkah analisis yaitu data hasil pre-test dan post-test disusun dalam bentuk tabel kemudian menentukan nilai rata-rata dan standar deviasi dari kedua data sampel, menghitung uji normalitas, uji homogenitas, dan uji hipotesis. Setelah t diketahui, maka nilai tersebut akan dikonsultasikan dengan tabel pada taraf signifikan 5\% dengan $\mathrm{dk}=\mathrm{n}-1$ pada taraf nyata $\alpha=0,05$. Dengan demikian, jika $t_{\mathrm{o}}>\mathrm{t}_{\mathrm{t}}$ pada taraf nyata $\alpha=0,05$ maka Ha diterima.

\section{HASIL PENELITIAN DAN PEMBAHASAN}

\section{Hasil Penelitian}

a. Kemampuan Menulis Teks Prosedur Kompleks sebelum Menggunakan Model Pembelajaran Experiential Learning dengan Media Audiovisual

Kemampuan menulis teks prosedur kompleks sebelum menggunakan model pembelajaran experiential learning dengan media audiovisual pada siswa kelas X SMA Negeri 5 Medan tahun pembelajaran 2016/2017 memperoleh nilai rata-rata sebesar 57,62 dengan nilai terendah 40 dan nilai tertinggi 80. Berikut ini persentase nilai siswa yang berada pada kategori baik sebanyak 7 siswa (17,5\%), kategori cukup sebanyak 22 siswa (55\%), kategori kurang sebanyak 7 siswa (17,5\%), dan kategori sangat kurang 4 siswa (10\%). Nilai tersebut menunjukkan kemampuan menulis teks prosedur kompleks siwa terdapat pada kategori kurang.

b. Kemampuan Menulis Teks Prosedur Kompleks Sesudah Menggunakan Model Pembelajaran Experiential Learning dengan Media Audiovisual

Kemampuan menulis teks prosedur kompleks sesudah menggunakan model pembelajaran experiential learning dengan media audiovisual pada siswa kelas X SMA Negeri 5 Medan tahun pembelajaran 2016/2017 memperoleh nilai rata-rata sebesar 80,27 dengan nilai terendah 65 dan nilai tertinggi 95. Berikut ini persentase nilai siswa yang berada pada kategori sangat baik sebanyak 15 siswa (37,5\%), kategori baik sebanyak 22 siswa (55\%), dan kategori cukup sebanyak 3 siswa (7,5\%). Nilai tersebut menunjukkan kemampuan menulis teks prosedur kompleks siwa terdapat pada kategori baik.

c. Pengaruh Model Pembelajaran Experiential Learning dengan Media Audiovisual Terhadap Kemampuan Menulis Teks Prosedur Kompleks 
Berdasarkan uji analisis data normalitas yang diperoleh siswa, dapat dibuktikan bahwa data berdistribusi normal. Hal ini dapat dilihat dari uji normalitas pre-test yaitu $\mathrm{L}_{\text {hitung }}<\mathrm{L}_{\text {tabel }}(0,130<0,140)$ dan uji normalitas post-test yaitu $\mathrm{L}_{\text {hitung }}<\mathrm{L}_{\text {tabel }}(0,111<0,140)$. Dari uji homogen diperoleh $\mathrm{F}_{\text {hitung }}=1,64<\mathrm{F}_{\text {tabel }}=1,69$ yang berarti sampel ini berasal dari populasi yang homogen. Setelah data terbukti normal dan homogen, maka uji hipotesis dapat dilakukan. Dari pengujian hipotesis diperoleh bahwa $t_{0}>t_{t}$ yakni 10,58>2,02. Maka hipotesis alternatif (Ha) diterima. Dengan demikian, model pembelajaran experiential learning dengan media audiovisual berpengaruh terhadap kemampuan menulis teks prosedur kompleks pada siswa kelas X SMA Negeri 5 Medan tahun pembelajaran 2016/2017.

\section{Pembahasan Hasil Penelitian}

a. Kemampuan menulis teks prosedur kompleks sebelum menggunakan Model pembelajaran experiential learning dengan media audiovisual

Penelitian ini merupakan penelitian eksperimen dengan menggunakan model onegroup pre-test dan post-test. Data yang diperoleh dari penelitian ini adalah data menulis teks prosedur kompleks oleh siswa kelas X SMA Negeri 5 Medan Tahun Pembelajaran 2016/2017, yang menjadi sampel adalah kelas X MIA 5 dengan jumlah siswa sebanyak 40 orang.

Data awal mengenai kemampuan menulis teks prosedur kompleks diperoleh melalui tes awal (pre-test) pada pertemuan pertama. Saat pre-test ini siswa diberi kesempatan untuk menulis teks prosedur kompleks sesuai dengan pengetahuan dan kemampuan mereka masing-masing, tanpa memperoleh bimbingan dan arahan selama proses menulis.

Setelah dilakukan tes awal (pre-test), diperoleh nilai rata-rata kemampuan menulis teks prosedur kompleks siswa sebelum menggunakan model pembelajaran experiential learning dengan media audiovisual, yaitu 57,62 dengan kategori kurang. Apabila ditinjau dari KKM (Kriteria Ketuntasan Minimal), maka nilai rata-rata menulis teks prosedur kompleks siswa termasuk kategori tidak tuntas karena berada di bawah nilai 75. Hal itu terlihat dari persentase nilai siswa yang berada pada kategori baik sebanyak 7 siswa (17,5\%), kategori cukup sebanyak 22 siswa (55\%), kategori kurang sebanyak 7 siswa $(17,5 \%)$, dan kategori sangat kurang 4 siswa (10\%).

Pada tahap pre-test ini siswa kurang memahami aspek-aspek yang harus diperhatikan dalam indikator menulis teks prosedur kompleks, baik yang berhubungan dengan isi, struktur teks, kalimat, kosa kata, dan mekaniknya. Rendahnya hasil belajar siswa dalam menulis teks prosedur kompleks ini disebabkan siswa masih berlatih dengan menggunakan model pembelajaran yang konvensional yang membuat mereka jenuh 
sehingga tidak ada keaktifan siswa belajar dalam kelas. Sebelum penerapan model pembelajaran experiential learning dengan media audiovisual ini siswa berlatih untuk meningkatkan kemampuan menulis teks prosedur kompleks hanya dengan menuliskan apa yang mereka tahu saja tanpa diberikan arahan yang menarik siswa untuk berpikir secara logis dan sistematis.

b. Kemampuan menulis teks Prosedur kompleks sesudah menggunakan model Pembelajaran experiential learning dengan media audiovisual

Hasil kemampuan menulis teks teks prosedur kompleks diperoleh melalui tes akhir atau post-test. Kegiatan pembelajaran diawali dengan membagi siswa dalam beberapa kelompok. Kemudian, setiap kelompok ditugaskan memahami materi konsep dasar teks prosedur kompleks dan mengidentifikasi struktur dan ciri kebahasaannya. Selanjutnya, guru melaksanakan proses pembelajaran dengan menggunakan model pembelajaran experiential learning dengan pendekatan saintifik. Setiap anggota kelompok mendapatkan materi yang sama yaitu tentang pengalaman. Guru menugaskan siswa mengamati melaui tayangan video prosedur, seperti cara mencangkok, cara membuat jus spesial, dan cara membuat layangan. Untuk kegiatan lebih lanjut guru menugaskan siswa untuk mengamati orang tua mereka dalam melakukan kegiatan prosedur supaya menambah pengalaman siswa. Setelah itu, Siswa berdiskusi dan berbagi pengalaman mereka bersama dengan kelompoknya. Dalam kegiatan ini siswa mengaitkan pengalaman kegiatan prosedur mereka dengan pembelajaran teks prosedur kompleks. Pada akhir pertemuan siswa ditugaskan berlatih menulis pengalaman kegiatan prosedur mereka.

Setelah siswa dirasa cukup paham tentang konsep dasar, struktur, dan ciri kebahasaan teks prosedur kompleks, kemudian dilanjutkan dengan berlatih menulis teks prosedur kompleks dengan memperhatikan strukturnya dan ciri kebahasaannya. Kemudian guru memeriksa hasil latihan siswa dan memperbaiki hal-hal yang kurang. Pada pertemuan terakhir guru menugaskan siswa untuk membuat teks teks prosedur kompleks kembali sebagai tes akhir atau post-test.

Dari hasil post-test yang dikumpulkan oleh siswa, diperoleh nilai rata-rata kemampuan menulis teks prosedur kompleks siswa sesudah menggunakan model pembelajaran experiential learning dengan media audiovisual, yaitu 80,27 dengan kategori baik, apabila ditinjau dari KKM (Kriteria Ketuntasan Minimal), maka nilai ratarata menulis teks teks prosedur kompleks siswa termasuk kategori tuntas karena berada di atas nilai 75. Hal itu terlihat dari persentase nilai siswa yang berada pada kategori sangat 
baik sebanyak 15 siswa (37,5\%), kategori baik sebanyak 22 siswa (55\%), dan kategori cukup sebanyak 3 siswa (7,5\%).

Dengan demikian, model pembelajaran experiential learning dengan media audiovisual memberikan pengaruh terhadap kemampuan menulis teks prosedur kompleks. Hal ini sesuai pendapat Indriana (2011:90), menyatakan “Experiential Learning merupakan model yang bertujuan untuk mengembangkan pengetahuan dan keterampilan siswa melalui pengalaman." dan pendapat Fathurrohman (2015:138), menyatakan "Kelebihan dari model pembelajaran experiential learning adalah hasil yang dapat dirasakan bahwa pembelajaran lewat pengalaman lebih efektif dan dapat mencapai tujuan secara maksimal." Melalui penerapan model ini dalam pembelajaran, hasil belajar siswa dapat maksimal. Siswa juga dapat mengerti bahwa pengalaman dapat dikaitkan dengan pembelajaran bahasa indonesia.

\section{c. Pengaruh model pembelajaran experiential learning dengan media audiovisual terhadap kemampuan menulis teks prosedur kompleks \\ Sebagaimana disajikan pada hasil penelitian yang menunjukkan nilai rata-rata untuk} kemampuan menulis teks prosedur kompleks siswa pada tahap sebelum penerapan model pembelajaran Experiential Learning dengan media audiovisual tergolong pada kategori kurang dengan nilai rata-rata 57,62 dibandingkan dengan tahap sesudah diterapkan model pembelajaran Experiential Learning dengan media audiovisual yang berkategori baik dengan nilai rata-rata 80,27 . Sehingga dari data tersebut disimpulkan bahwa model pembelajaran experiential learning dengan media audiovisual berpengaruh dalam meningkatkan kemampuan menulis teks prosedur kompleks.

Hal ini sesuai dengan hasil yang diharapkan untuk meningkatkan hasil belajar siswa dan juga mencapai KKM yang sudah ditentukan sekolah tersebut. Model pembelajaran experiential learning merupakan sebuah model pembelajaran berbasis pengalaman yang pada pembelajarannya ditujukan untuk menggali kembali pengalaman siswa kemudian dituangkan kedalam pembelajaran. Pembelajaran menggunakan model ini menekankan pada konsep berpikir kritis yang dapat membantu siswa mengingat kembali pengalaman belajarnya dan memalui ide kreatif mampu mengembangkan gagasannya dalam belajar. Selain itu model pembelajaran ini dapat membangkitkan motivasi siswa untuk berperan aktif dalam belajar dan berbagi pengalaman dengan siswa lain serta mampu menulis teks sesuai dengan ciri dan kaidah bahasa teks prosedur kompleks.

\section{PENUTUP}


Berdasarkan hasil penelitian yang telah diuraikan pada pembahasan dapat diambil simpulan yaitu kemampuan menulis teks prosedur kompleks pada siswa kelas X SMA Negeri 5 Medan tahun pembelajaran 2016/2017 sebelum menggunakan model pembelajaran experiential learning dengan media audiovisual berada pada kategori kurang dengan nilai rata-rata sebesar 57,62. yaitu kemampuan menulis teks prosedur kompleks pada siswa kelas X SMA Negeri 5 Medan tahun pembelajaran 2016/2017 sesudah menggunakan model pembelajaran experiential learning dengan media audiovisual berada pada kategori baik dengan nilai rata-rata sebesar 80,27 . Sedangkan uji normalitas pre-test yaitu $\mathrm{L}_{\text {hitung }}<\mathrm{L}_{\text {tabel }}$ $(0,130<0,140)$ dan uji normalitas post-test yaitu $\mathrm{L}_{\text {hitung }}<\mathrm{L}_{\text {tabel }}(0,111<0,140)$ yang membuktikan data berdistribusi normal. Dari uji homogen diperoleh $F_{\text {hitung }}=1,64<\mathrm{F}_{\text {tabel }}=1,69$ yang berarti sampel ini berasal dari populasi yang homogen. Setelah data terbukti normal dan homogen, maka uji hipotesis dapat dilakukan. Dari pengujian hipotesis dengan $\mathrm{dk}=\mathrm{n}-1$ pada taraf signifikan 5\% diperoleh bahwa $t_{0}>t_{t}$ yakni 10,58>2,02. Maka hipotesis alternatif (Ha) diterima. Dengan demikian, model pembelajaran experiential learning dengan media audiovisual berpengaruh terhadap kemampuan menulis teks prosedur kompleks pada siswa kelas X SMA Negeri 5 Medan tahun pembelajaran 2016/2017.

\section{DAFTAR PUSTAKA}

Arikunto, Suharsimi. 2009. Prosedur Penelitian: Suatu Pendekatan Praktik. Jakarta: Rineka Cipta.

Depdiknas. 2008. Kamus Besar Bahasa Indonesia. Jakarta: Balai Pustaka

Fathurrohman, Muhammad. Model-Model Pembelajaran Inovatif. Yogyakarta: Arr-ruz Media

Indriana, Dina. 2012. Mengenal Ragam Gaya Pembelajaran Efektif. Yogyakarta: DIVA Press.

Nurgiyantoro.2012. Penilaian dalam Pembelajaran Bahasa dan Sastra. Yogyakarta: BPFE.

Sanjaya, Wina. 2014. Strategi Pembelajaran: Berorientasi Standar Proses Pendidikan. Jakarta: Prenada Media

Suparno dan Yunus, Moh. 2009. Keterampilan Dasar Menulis. Jakarta: Universitas Terbuka

Tarigan, H.G. 1986. Menulis sebagai suatu keterampilan berbahasa. Bandung: Angkasa.

Trimantara, Petrus. 2005. Metode Sugesti-Imajinasi dalam Pembelajaran Menulis dengan Media Lagu. Bandung: Jurnal Pendidikan BPK Penabur 